\title{
Sylfation of Birch Wood Xylan with Sulfamic Acid in 1,4-dioxane
}

\author{
Vladimir A. Levdansky a, Alexander A. Kondrasenko $0^{a}$, \\ Alexander V. Levdansky ${ }^{a}$ and Boris N. Kuznetsov ${ }^{a}$, b \\ anstitute of Chemistry and Chemical Technology SB RAS \\ FRC KSC SB RAS \\ Krasnoyarsk, Russian Federation \\ ${ }^{b}$ Siberian Federal University \\ Krasnoyarsk, Russian Federation
}

Received 18.06.2021, received in revised form 30.06.2021, accepted 16.08.2021

\begin{abstract}
Sulfation of birch wood xylan in 1,4-dioxane by sulfamic acid in the presence of urea at 90 and $100{ }^{\circ} \mathrm{C}$ was studied for the first time. The effect of the duration of xylan sulfation on the yield of xylan sulfates and the sulfur content in them was studied. It was found that the sulfur content in the obtained xylan sulfates increases from 12.5 to $17.5 \mathrm{wt} \%$ with an increase in the duration of sulfation from 2 to 4 hours. The structure of initial and sulfated xylan was studied by FTIR and NMR spectroscopy. The ease of purification of the obtained xylan sulfates from 1,4-dioxane in comparison with the purification of xylan sulfates obtained by sulfation in pyridine and N, N-dimethylformamide is an advantage of the proposed method of xylan sulfation.
\end{abstract}

Keywords: xylan, sulfation, sulfamic acid, urea, 1,4-dioxane, xylan sulfate.

Citation: Levdansky, V.A., Kondrasenko, A.A., Levdanskya, A.V., Kuznetsov, B.N. Sylfation of birch wood xylan with sulfamic acid in 1,4-dioxane, J. Sib. Fed. Univ. Chem., 2021, 14(3), 325-336. DOI: 10.17516/1998-2836-0241

(C) Siberian Federal University. All rights reserved

This work is licensed under a Creative Commons Attribution-NonCommercial 4.0 International License (CC BY-NC 4.0).

* Corresponding author E-mail address: inm@icct.ru 


\title{
Сульфатирование ксилана древесины березы сульфаминовой кислотой в 1,4-диоксане
}

\author{
В. А. Левданский ${ }^{a}$ А. А. Кондрасенко ${ }^{a}$, \\ А.В. Левданский ${ }^{\mathrm{a}}$, Б. Н. Кузнецов ${ }^{\mathrm{a},}$ б* \\ ${ }^{a}$ Институт химии и химической технологии СО РАН \\ ФИЦ КНЦ СО РАН \\ Российская Федерачия, Красноярск \\ ${ }^{6}$ Сибирский федеральный университет \\ Российская Федерация, Красноярск
}

\begin{abstract}
Аннотация. Впервые изучено сульфатирование в среде 1,4-диоксана, выделенного из древесины березы ксилана, сульфаминовой кислотой в присутствии мочевины при температуре 90 и $100{ }^{\circ} \mathrm{C}$. Изучено влияние продолжительности сульфатирования ксилана на выход сульфатов ксилана и содержание в них серы. Установлено, что содержание серы в полученных сульфатах ксилана возрастает от 12,5 до 17,5 \% масс при увеличении продолжительности сульфатирования от 2 до 4 ч. Строение исходного и сульфатированного ксилана изучено методами ИК- и ЯМР-спектроскопии. Преимуществом предложенного метода сульфатирования ксилана является легкость очистки полученных сульфатов от 1,4-диоксана по сравнению с сульфатированием в пиридине и $\mathrm{N}$, N-диметилформамиде.
\end{abstract}

Ключевые слова: ксилан, сульфатирование, сульфаминовая кислота, мочевина, 1,4-диоксан, сульфат ксилана.

Цитирование: Левданский, В. А. Сульфатирование ксилана древесины березы сульфаминовой кислотой в 1,4-диоксане / В. А. Левданский, А. А. Кондрасенко, А. В. Левданский, Б. Н. Кузнецов // Журн. Сиб. федер. ун-та. Химия, 2021, 14(3). C. 325-336. DOI: 10.17516/1998-2836-0241

\section{Введение}

Гемицеллюлозы, составляющие до 15-40 \% от массы лигноцеллюлозной биомассы, в отличие от целлюлозы, представляют собой $(1 \rightarrow 4)-\beta$-связанные полиглюканы. Гемицеллюлозы имеют сложную структуру, которая содержит звенья глюкозы, ксилозы, арабинозы, манозы, галактозы, глюкуроновой и галактуроновой кислот в различных соотношениях, зависящих от природы биомассы [1]. Среди моносахаридных звеньев гемицеллюлоз могут преобладать следующие: ксилан, маннан, $\beta$-глюкан и ксилоглюкан. Ксилан - наиболее распространенный полисахарид гемицеллюлоз многих видов растений. Содержание его в древесине березы достигает 19 \% [2]. Ксилан и его простые и сложные эфиры используют в пищевой, парфюмерной и фармацевтической промышленности в качестве безвредного загустителя, эмульгатора и стабилизатора. Он является сырьем для получения ксилита, ксилозы, органических кислот, кормовых дрожжей и многих товарных продуктов [3, 4]. Известно, что сульфаты полисахаридов обладают антикоагулянтными свойствами и могут применяться для профилактики и лечения тромбозов 
взамен получаемого из животного сырья гепарина, который может содержать патогенные для человека микроорганизмы [5].

Сульфат ксилана (коммерческое название Elmiron) применяется в качестве лекарственного средства для лечения цистита и боли в мочевом пузыре [6]. Кроме того, сульфат ксилана обладает широким спектром биологической активности, таких как противовирусная, противовоспалительная и противоопухолевая, и подавляет ВИЧ-инфекции $[7,8]$.

В последние годы большое внимание уделяется разработке новых технологичных способов получения сульфатированных полисахаридов растительного происхождения и изучению их биологической активности. При сульфатировании полисахаридов в качестве сульфатирующих агентов нашли широкое применение комплексы серного ангидрида с пиридином и другими аминами. Сульфатирование полисахаридов проводят в дихлорэтане, уксусном ангидриде, $\mathrm{N}, \mathrm{N}$-диметилформамиде, пиридине [9-12]. Высокая степень сульфатирования ксилана достигается при использовании хлорсульфоновой кислоты. Сульфатирование ксилана хлорсульфоновой кислотой проводят в пиридине в присутствии $\mathrm{N}, \mathrm{N}$-диметилформамида при температуре $75{ }^{\circ} \mathrm{C}$ в течение 4 ч [10].

Важной характеристикой для применения сульфатов ксилана в медицинских целях выступает их структурная чистота. Однако, как показано в работе [13], при сульфатировании ксилана комплексом $\mathrm{SO}_{3}$-пиридин молекулы пиридина могут ковалентно связываться с восстанавливающими концевыми группами ксилана, образуя производное $\mathrm{N}-\alpha$-D-ксилопиранозилпиридиния. Для получения более чистых сульфатов ксилана при использовании комплексов $\mathrm{SO}_{3}$-пиридин перед сульфатированием полисахарида проводят его обработку боргидридом натрия [14].

Анализ публикаций за последние $10-15$ лет показал, что $\mathrm{ClSO}_{3} \mathrm{H}$ в сочетании с различными основаниями наиболее широко используется для сульфатирования различных полисахаридов. Большое внимание уделено изучению сульфатирования целлюлозы и гемицеллюлозы комплексом $\mathrm{SO}_{3}$-пиридин и $\mathrm{SO}_{3}$-ДМФА, полученными с использованием $\mathrm{SO}_{3}$ и $\mathrm{ClSO}_{3} \mathrm{H}$. Недостатком сульфатирования $\mathrm{ClSO}_{3} \mathrm{H}$ в пиридине и ДМФА, а также в смеси пиридина с ДМФА являются, во-первых, высокая агрессивность сульфатирующих агентов, что приводит к деструкции полимера, во-вторых, продукты сульфатирования могут быть загрязнены пиридином и ДМФА.

В работе [15] нами впервые было показано, что сульфаминовая кислота $\left(\mathrm{NH}_{2} \mathrm{SO}_{3} \mathrm{H}\right)$ может с успехом заменить агрессивные и неудобные в использовании $\mathrm{SO}_{3}$ и $\mathrm{ClSO}_{3} \mathrm{H}$ при сульфатировании ксилана. В литературе отсутствуют данные о сульфатировании ксилана сульфаминовой кислотой в 1,4-диоксане в присутствии мочевины. Высокая каталитическая активность мочевины при сульфатировании полисахаридов сульфаминовой кислотой показана в работах $[15,16]$.

Известно, что биологическая активность сульфатов ксилана зависит от молекулярной массы и степени сульфатирования [17]. Поэтому разработка эффективных методов сульфатирования ксилана, позволяющих снизить его деполимеризацию в ходе получения и добиться высокой степени сульфатирования, считается актуальной задачей. Ранее нами изучено сульфатирование ксилана древесины березы сульфаминовой кислотой в N, N-диметилформамиде [15].

Цель данной работы заключается в разработке эффективного способа сульфатирования ксилана, позволяющего достичь высокого содержания серы в получаемых сульфатах ксилана и исключить их загрязнения пиридином и ДМФА.

$$
-327-
$$




\section{Экспериментальная часть}

В качестве исходного сырья использовали древесину березы (Betula pendula Roth.), заготовленную в окрестностях г. Красноярска. Содержание основных компонентов в древесине березы, определенное известным методом [18], составляло (\% вес): целлюлоза - 41,3, гемицеллюлозы и уроновые кислоты - 30,3, лигнин - 19,9, экстрактивные вещества $-4,2$, зола - 0,3. Древесину березы измельчали и в экспериментах использовали фракцию 3-5 мм.

Для сульфатирования использовали ксилан, выделенный из древесины березы после предварительной делигнификации древесины березы в среде «уксусная кислота - пероксид водорода - вода - сернокислотный катализатор» и последующей экстракцией ксилана 5 \%-ным водным раствором гидроксида натрия из образующегося целлюлозного продукта по методике, приведенной в работе [15].

Анализ химического состава полученного ксилана проводили известным методом [19], он включал гидролиз ксилана и последующий хроматографический анализ.

\section{Гидролиз ксилана}

Гидролиз ксилана осуществляли при температуре $130{ }^{\circ} \mathrm{C}$ во вращающемся стальном автоклаве с внутренней фторопластовой пробиркой объемом 35 мл, помещенном в металлический воздушный термостат. Скорость вращения автоклава составляла 11 об/мин. Навеску ксилана в количестве 0,100 г помещали в пробирку, заливали 1,0 мл 0,3 \% раствора серной кислоты и выдерживали в течение 6 ч. По истечении заданного времени реактор охлаждали, реакционный раствор нейтрализовали 2 \%-ным водным раствором $\mathrm{NaHCO}_{3}$.

\section{Анализ полученных гидролизатов}

Для хроматографического анализа полученных триметилсилильных производных гидролизатов использовали газовый хроматограф «Varian-450 GC» с плазменно-ионизационным детектором и капиллярной колонкой VF-624ms длиной 30 м, внутренним диаметром 0,32 мм. Условия хроматографирования: газ-носитель - гелий; температура инжектора $250{ }^{\circ} \mathrm{C}$; начальная температура термостата колонки $50{ }^{\circ} \mathrm{C}\left(5\right.$ мин), подъем температуры до $180{ }^{\circ} \mathrm{C}$ со скоростью $10{ }^{\circ} \mathrm{C} /$ мин, выдержка при $180{ }^{\circ} \mathrm{C} 37$ мин. Температура детектора $280{ }^{\circ} \mathrm{C}$. Продолжительность хроматографического разделения моносахаридов равнялась 55 мин. Для регистрации выхода олигосахаридов после 55 мин анализа температуру термостата поднимали до $250{ }^{\circ} \mathrm{C}\left(10{ }^{\circ} \mathrm{C} /\right.$ мин) и выдерживали колонку при данной температуре 30 мин. Общее время анализа при этом составляло 92 мин.

Пробу гидролизата подвергали дериватизации по методике [19] с образованием триметилсилильных производных. В качестве силирующего реагента использовали смесь триметилхлорсилана и гексаметилдисилазана в среде пиридина, а в качестве внутреннего стандарта сорбит. Полученная хроматограмма включает пики всех содержащихся в пробе гидролизата таутомеров моносахаридов. Идентификацию пиков проводили, пользуясь значениями времен удерживания таутомерных форм моносахаридов. Рассчитывали отношение суммы площадей характеристических пиков моносахарида к площади пика внутреннего стандарта ( $\mathrm{Si} / \mathrm{Sct})$. По этим соотношениям с помощью градуировочного графика находили массу каждого моносахарида в пробе гидролизата. 
В качестве стандартов для анализа использовали следующие моносахара: глюкоза кристаллическая гидратная (ГОСТ 975-88), D-ксилоза 142080.1208 (Panreac), D-манноза 373195.1208 (Panreac), D-галактоза 372173 (Panreac), L-арабиноза 375765.1206, D-сорбит (Panreac). Xроматографический анализ полученного из ксилана гидролизата показал, что он содержит 95,13% ксилозы, 1,52 \% маннозы, 1,48 \% глюкозы, 0,97 \% галактозы и 0,89 \% арабинозы.

В ИК-спектре ксилана отсутствуют характерные для лигнина полосы поглощения при 1645 и 1662 см$^{-1}$ валентных колебаний $\mathrm{C}=\mathrm{C}$ - и $\mathrm{C}=\mathrm{O}$-связей, сопряженных с ароматическим кольцом v $(\mathrm{C}=\mathrm{C})$, а также полосы $1330 \mathrm{~cm}^{-1}$, обусловленные колебаниями ароматических колец с валентными колебаниями С-O [18]. Следовательно, ксилан не содержит значительного количества лигнина.

Сульфатирование ксилана осуществляли по методике, аналогичной используемой в работе [15] для сульфатирования в среде N, N-диметилформамида.

В трехгорлую колбу объемом 100 мл, снабженную мешалкой, термометром и обратным холодильником, снабженным хлоркальциевой трубкой, заливали 35 мл 1,4-диоксана, загружали 1,00 г ксилана, выделенного из древесины березы, 2,20 г сульфаминовой кислоты и 1,36 г мочевины и перемешивали при 90-100 ${ }^{\circ} \mathrm{C}$ в течение 2,0-6,0 ч. Реакционную массу охлаждали до температуры $15-20{ }^{\circ} \mathrm{C}$ и при перемешивании нейтрализовали 40 мл 5 \%-ного водного раствора гидроксида натрия до рН 9-10. Полученную реакционную смесь концентрировали под вакуумом на ротационном испарителе при температуре водяной бани $50{ }^{\circ} \mathrm{C}$ до полного удаления растворителя. Затем полученный продукт растворяли в 50 мл дистиллированной воды и фильтровали. Полученный фильтрат очищали диализом. Использовали диализный мешок MF-8030-25 MFPI (США) размером пор 6-8 кДа, шириной 25 мм. Водный раствор сульфата ксилана после диализа концентрировали под вакуумом на ротационном испарителе при температуре водяной бани $50{ }^{\circ} \mathrm{C}$ до полного удаления воды.

Содержание серы определяли на элементном анализаторе «Flash EA-1112» (Thermo Quest, Италия).

ИК-спектры ксилана и сульфатов ксилана регистрировали с использованием ИК-Фурье спектрометра IR Tracer-100 (Shimadzu, Япония) в области длин волн 400-4000 см-1. Обработка спектральной информации проведена по программе OPUS (версия 5.0). Твердые образцы для анализа готовили в виде таблеток в матрице $\mathrm{KBr}$ (2 мг образца / 1000 мг KBr).

ЯМР ${ }^{13} \mathrm{C}$ спектры исходного и сульфатированного ксилана регистрировали в среде $\left(\mathrm{CD}_{3}\right)_{2} \mathrm{SO}$ и $\mathrm{D}_{2} \mathrm{O}$ при температуре $25^{\circ} \mathrm{C}$ с использованием спектрометра Bruker Avance III 600 МГц с привязкой к дейтериевому резонансу растворителя. Двумерные спектры ЯМР регистрировали при $25^{\circ} \mathrm{C}$ в 5 мм ампулах, рабочая частота 600 МГц $\left({ }^{1} \mathrm{H}\right)$ и 155 МГц $\left({ }^{13} \mathrm{C}\right)$. Около 80 мг образца растворяли в 0,6 мл дейтерированной воды, затем спектры записывали в HSQC (Heteronuclear Single Quantum Correlation) экспериментах с редактированием из библиотеки стандартных последовательностей Bruker.

\section{Результаты и обсуждение}

Реакцию сульфатирования ксилана сульфаминовой кислотой проводили в среде 1,4-диоксана в присутствии мочевины при температуре 90-100 ${ }^{\circ} \mathrm{C}$. Продолжительность реакции сульфатирования варьировали от 2 до 6 ч. Сульфат ксилана выделяли в виде натриевой соли (рис. 1). 


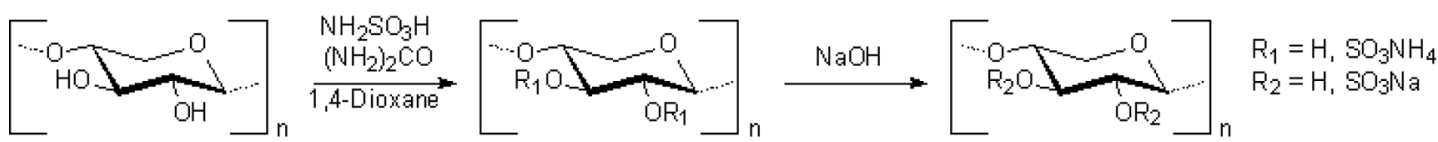

Рис. 1. Схема реакции сульфатирования элементарного звена ксилана сульфаминовой кислотой

Fig. 1. Scheme of the sulfation reaction of an elementary unit of xylan with sulfamic acid

Таблица 1. Результаты сульфатирования ксилана березы смесью сульфаминовой кислоты и мочевины в среде 1,4-диоксана

Table 1. Results of sulfation of birch xylan with a mixture of sulfamic acid and urea in 1,4-dioxane medium

\begin{tabular}{|c|c|c|c|c|}
\hline № & $\begin{array}{c}\text { Температура } \\
\text { реакции, }{ }^{\circ} \mathrm{C}\end{array}$ & Продолжительность, ч & $\begin{array}{c}\text { Выход* сульфата } \\
\text { ксилана, } \Gamma\end{array}$ & $\begin{array}{c}\text { Содержание } \\
\text { серы, } \% \text { масс. }\end{array}$ \\
\hline 1 & 90 & 2 & 1,06 & 12,5 \\
\hline 2 & 90 & 3 & 1,15 & 15,7 \\
\hline 3 & 90 & 4 & 1,32 & 17,0 \\
\hline 4 & 90 & 5 & 1,31 & 16,7 \\
\hline 5 & 90 & 6 & 1,27 & 12,8 \\
\hline 6 & 100 & 2 & 1,09 & 16,4 \\
\hline 7 & 100 & 3 & 1,22 & 17,5 \\
\hline 8 & 100 & 4 & 1,29 & 16,8 \\
\hline
\end{tabular}

*Во всех экспериментах сульфатировали 1,00 г ксилана.

Данные о влиянии продолжительности сульфатирования на выход сульфатов ксилана и содержание в них серы приведены в табл. 1.

Как следует из приведенных в табл. 1 данных, при сульфатировании ксилана сульфаминовой кислотой в присутствии мочевины в среде 1,4-диоксана, максимальный выход сульфата ксилана $(1,29-1,32$ г) и высокое содержание в нем серы $(16,8-17,5$ \%) достигаются при температуре $90-100{ }^{\circ} \mathrm{C}$ и продолжительности реакции 4 ч. Увеличение продолжительности реакции до 5 ч при температуре $100{ }^{\circ} \mathrm{C}$ приводит к усилению процессов деструкции, что снижает выход сульфата ксилана до 1,26 г и снижает содержание в нем серы до 16,8 \%.

В ИК-спектре ксилана, полученного из древесины березы (рис. 2), присутствуют полосы валентных колебаний ОН-групп при $3434 \mathrm{~cm}^{-1}$ и СН-групп при $2922 \mathrm{~cm}^{-1}$, контуры полос, положения их максимумов в ИК-спектрах ксилана, приведенных в работах $[9,17,20,21]$, и полученного нами в области $1640-1630,1460-1440$ и 1200-1000 см-1 совпадает, что свидетельствует о подобии структур ксилана.

В отличие от исходного ксилана (рис. 2) в ИК-спектрах натриевых солей сульфатов ксилана (рис. 3) появляются новые интенсивные полосы, обусловленные валентными и деформационными колебаниями $\mathrm{SO}_{3}$-групп. Широкая полоса с максимумом при $1244 \mathrm{~cm}^{-1}$ обусловлена антисимметричными валентными колебаниями $v_{\mathrm{as}}\left(\mathrm{SO}_{2}\right)$, а широкая полоса с максимумом при $1008 \mathrm{~cm}^{-1}$ относится к симметричным валентным колебаниям $v_{\mathrm{s}}\left(\mathrm{SO}_{2}\right)$. Полоса с максимумом при 804 см$^{-1}$ принадлежит валентным колебаниям v(C-O-S). Низкочастотная полоса с макси- 


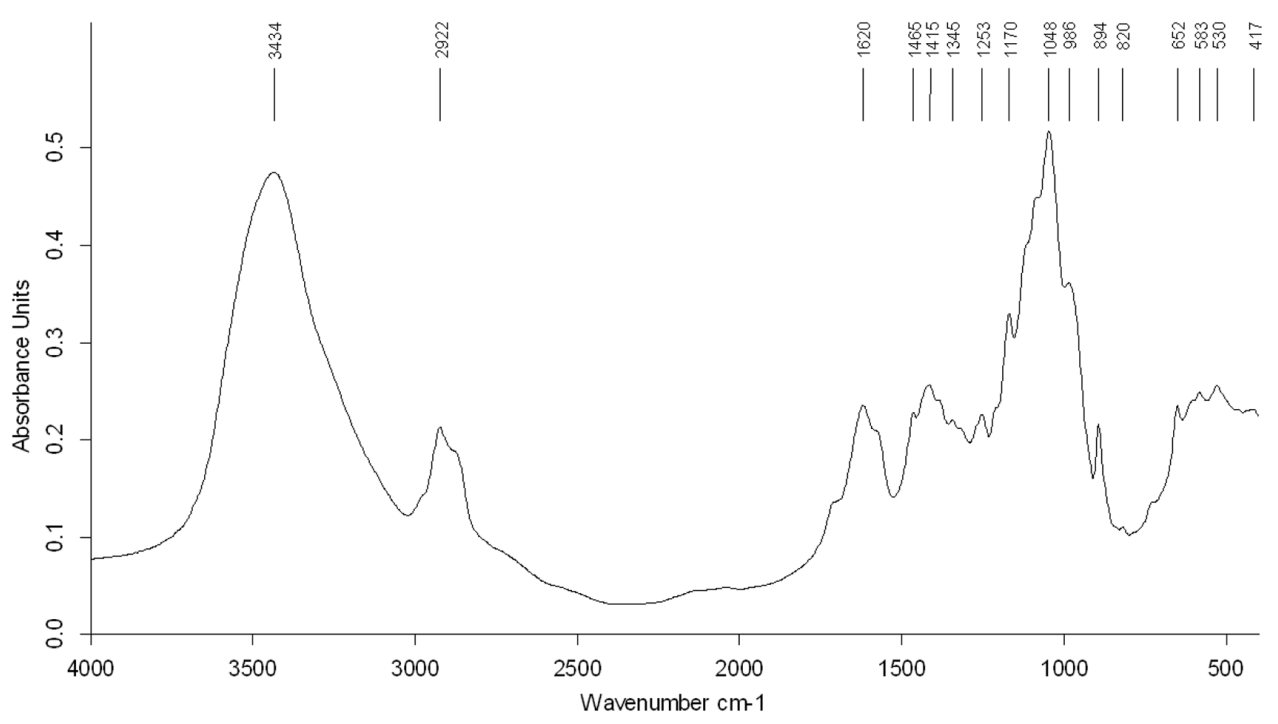

Рис. 2. ИК-спектр ксилана

Fig. 2. FTIR spectrum of xylan

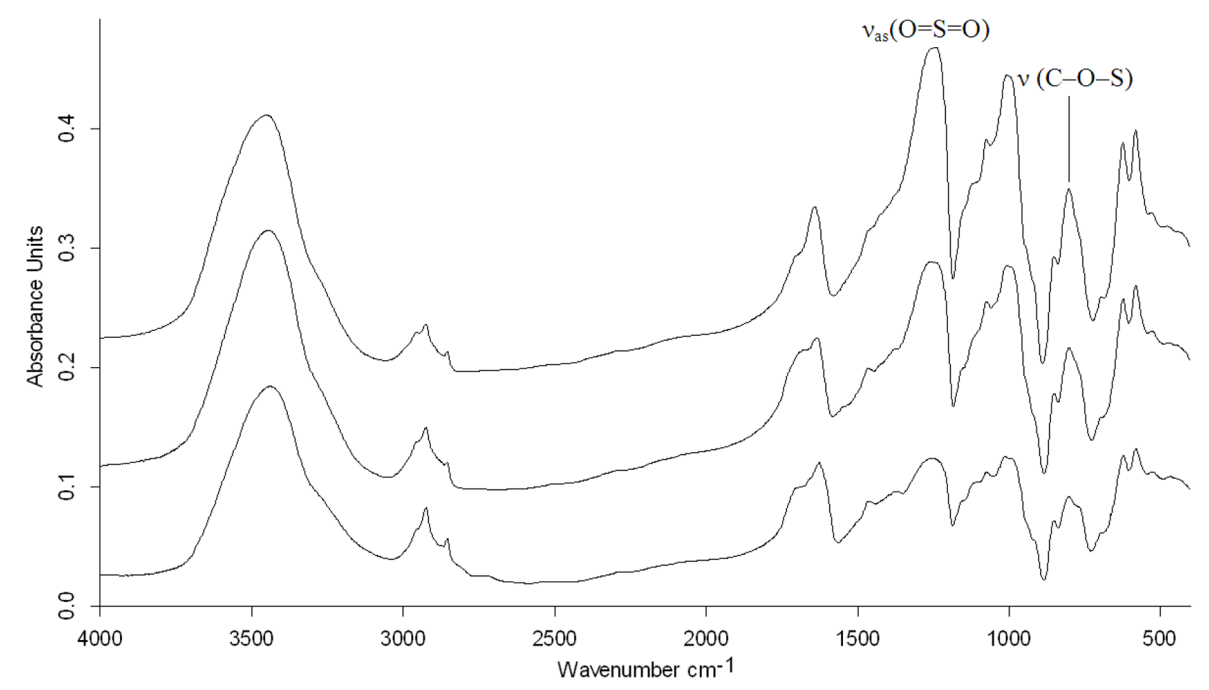

Рис. 3. ИК-спектры натриевых солей сульфатов ксилана, полученных при сульфатировании $1-90{ }^{\circ} \mathrm{C}, 4$ ч; $2-90{ }^{\circ} \mathrm{C}, 5$ ч; 3-100 ${ }^{\circ} \mathrm{C}, 4$ ч

Fig. 3. FTIR spectra of sodium salts of xylan sulfates obtained by sulfation $1-90{ }^{\circ} \mathrm{C}, 4 \mathrm{~h} ; 2-90{ }^{\circ} \mathrm{C}, 5 \mathrm{~h} ; 3-100{ }^{\circ} \mathrm{C}, 4 \mathrm{~h}$

мум при $583 \mathrm{~cm}^{-1}$ обусловлена деформационными колебаниями $\delta\left(\mathrm{SO}_{2}\right)$. Кроме того, снижение интенсивности полос поглощения С-ОН- группы при 2922 и 1047 см$^{-1}$ в спектре сульфатированного ксилана по сравнению с ксиланом указывает на замещение большинства гидроксильных групп [17].

В работе [11] методом ${ }^{13} \mathrm{C}$ ЯМР показано, что химические сдвиги атомов углерода $\mathrm{C} 1-\mathrm{C} 5$

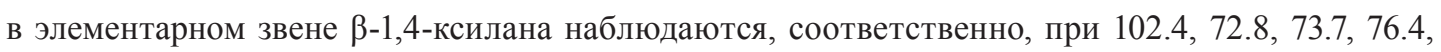


63.0 м. д., а в работе [17] - при 102.4, 73.4, 75.1, 75.8, 63.3 м. д. В ${ }^{13}$ С ЯМР спектре ксилана, выделенного нами из древесины березы, положение сигналов атомов углерода C1-C5 (102.3, 73.1, 74.6, 75.9, 63.8 м. д.) соответствует литературным данным.

Для исследования структуры сульфатов ксилана авторы работ $[11,13,14]$ использовали целый набор ЯМР-экспериментов ( ${ }^{1} \mathrm{H}$ ЯMP, ${ }^{13} \mathrm{C}$ ЯMP, ${ }^{1} \mathrm{H}-{ }^{1} \mathrm{H}$ COSY, ${ }^{1} \mathrm{H}-{ }^{13} \mathrm{C}$ HSQC и др.). Были установлены значения химических сдвигов атомов водорода и углерода основных $\beta$ D-ксилопиранозных звеньев сульфатированных ксиланов с различным содержанием сульфатных групп. Показано, что сульфатные группы вызывают в ${ }^{13} \mathrm{C}$ ЯМР спектре смещение в сильное поле сигналов атомов углерода, расположенных по соседству с атомами углерода, связанных с сульфатной группой [11]. Это дает возможность с помощью ${ }^{13} \mathrm{C}$ ЯMP и $2 \mathrm{D}$ HSQC спектроскопии установить наличие и положение сульфатных групп в полученных нами сульфатированных образцах ксилана.

На рис. 4 приведён ${ }^{13} \mathrm{C}$ ЯМР спектр, а в табл. 2 дано отнесение сигналов к соответствующим атомам углерода в звеньях сульфата ксилана, полученного сульфатированием ксилана древесины березы сульфаминовой кислотой в присутствии мочевины в среде 1,4-диоксана.

Как следует из приведенных в табл. 2 данных, в ${ }^{13} \mathrm{C}$ ЯМР спектре сульфата ксилана присутствуют сигналы всех пяти атомов углерода $\beta$-D-ксилозы и появляются дополнительные сигналы углеродных атомов, что свидетельствует о произошедших в макромолекуле ксилана изменениях в процессе сульфатирования.

Так, сигналы при 72.4 и 72.1 м. д. принадлежат, соответственно, С2 и С3 атомам $\beta$ D-ксилопиранозных звеньев, связанным с сульфатными группами. Подтверждением этого служит уменьшение интенсивности сигналов С2 атомов при 72.8 м. д. и С3 атомов при 73.7 м. д.,

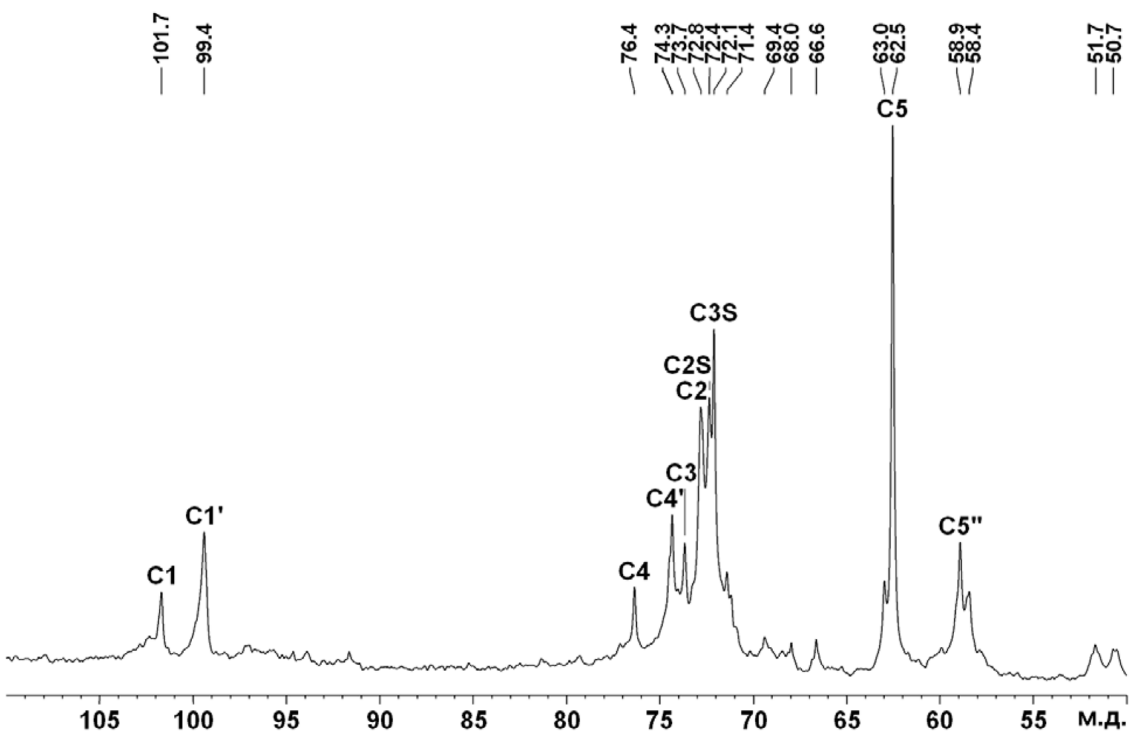

Рис. $4 .{ }^{13} \mathrm{C}$ ЯМР спектр сульфата ксилана (CS - сульфатированный в соответствующее положение, ' находящийся под влиянием сульфатирования в соседнее положение, " - находящийся под влиянием сульфатирования в положение С2 и/или С3)

Fig. $4 .{ }^{13} \mathrm{C}$ NMR spectrum of xylan sulfate (CS - sulfated in corresponding position, ' - influenced by sulfation in adjacent position, " - influenced by sulfation in $\mathrm{C} 2$ and/or $\mathrm{C} 3$ position) 
Таблица 2. Отнесение сигналов в ${ }^{13} \mathrm{C}$ ЯМР спектре сульфата ксилана, полученного сульфатированием ксилана смесью сульфаминовой кислоты и мочевины в среде 1,4-диоксана, к соответствующим атомам углерода (CS - сульфатированный в соответствующее положение, ' - находящийся под влиянием сульфатирования в соседнее положение, " - находящийся под влиянием сульфатирования в положение С2 и/или С3)

Table 2. Assignment of signals in the ${ }^{13} \mathrm{C}$ NMR spectrum of xylan sulfate, obtained by sulfation of xylan with a mixture of sulfamic acid and urea in a 1,4-dioxane medium, to the corresponding carbon atoms (CS - sulfated in corresponding position, ' - influenced by sulfation in adjacent position, " - influenced by sulfation in C2 and/or C3 position)

\begin{tabular}{|l|c|c|c|c|c|c|c|c|c|c|}
\hline № атома углерода & $\mathrm{C} 1$ & $\mathrm{C} 2$ & $\mathrm{C} 3$ & $\mathrm{C} 4$ & $\mathrm{C} 5$ & $\mathrm{C} 1{ }^{\prime}$ & $\mathrm{C} 2 \mathrm{~S}$ & $\mathrm{C} 3 \mathrm{~S}$ & C4' & C5" \\
\hline Химический сдвиг, м. д. & 101.7 & 72.8 & 73.7 & 76.4 & 62.5 & 99.4 & 72.4 & 72.1 & 74.3 & 58.9 \\
\hline
\end{tabular}

связанных со свободными вторичными гидроксильными группами. Кроме того, наличие сульфатных групп при C2 и C3 атомах у целого ряда $\beta$-D-ксилопиранозных звеньев сульфата ксилана подтверждается появлением дополнительных сигналов соседних углеродных атомов С1 при 99.4 м. д. и С4 при 74.3 м. д. Химические сдвиги C1 и C4 атомов $\beta$-D-ксилопиранозных звеньев сульфата ксилана, не содержащих сульфатных групп, составляют 101.7 м. д. и 76.4 м. д. соответственно. Аналогичное изменение химического сдвига, связанного с влиянием сульфатирования в положение С2 и/или С3, наблюдаются и для С5 атомов (сдвиг в сильное поле с 63.0 до 58.9 м. д.). В ${ }^{13} \mathrm{C}$ ЯМР спектре также присутствуют сигналы слабой интенсивности, относящиеся к атомам углерода концевых ангидроксилозных звеньев. Появление этих сигналов, возможно, обусловлено увеличением содержания концевых звеньев ксилана вследствие частичной деградации макромолекулы полимера в ходе реакции сульфатирования.

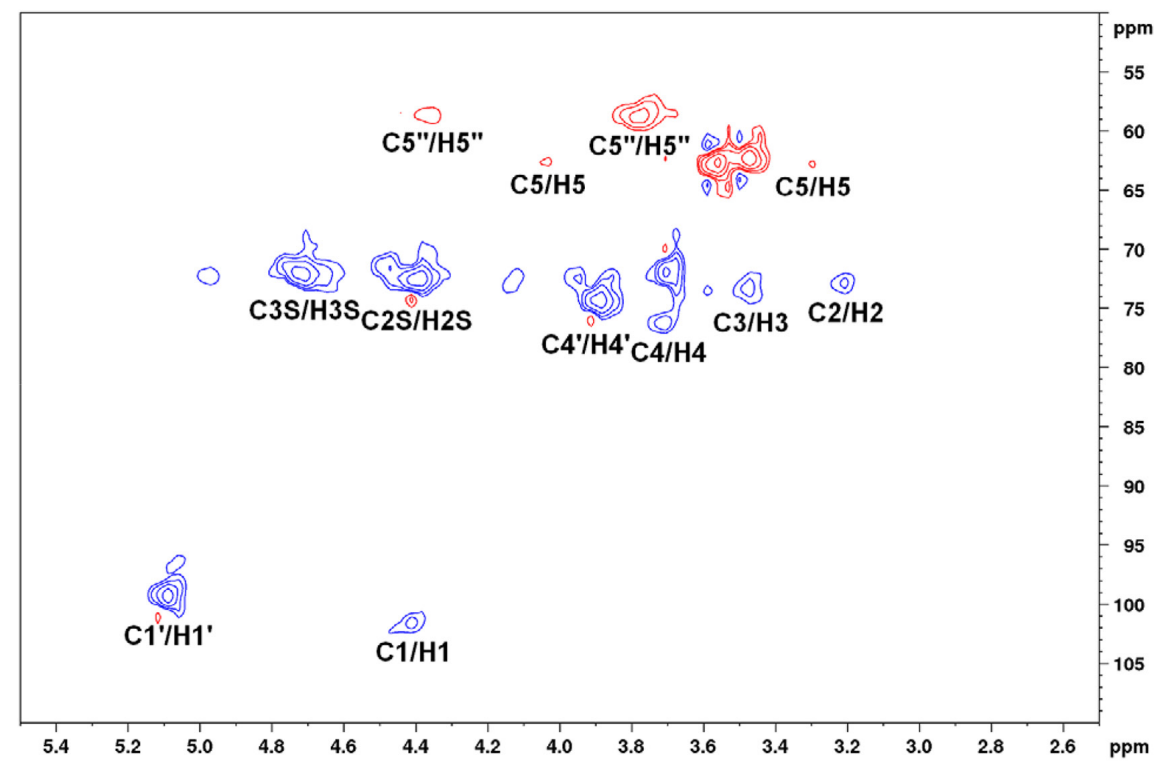

Рис. 5. HSQC спектр сульфата ксилана. Отнесение сигналов дано в табл. 3

Fig. 5. HSQC spectrum of xylan sulfate. The assignment of signals is given in Table 3 
Таблица 3. Отнесение ${ }^{1} \mathrm{H}^{13} \mathrm{C}$ кросс-сигналов в HSQC спектре сульфата ксилана, полученного сульфатированием смесью сульфаминовой кислоты и мочевины в 1,4-диоксане

Table 3. Assignment of ${ }^{1} \mathrm{H}^{-13} \mathrm{C}$ cross signals in the HSQC spectrum of xylan sulfate, obtained by sulfation with a mixture of sulfamic acid and urea in 1,4-dioxane

\begin{tabular}{|l|c|c|c|c|c|}
\hline Отнесение & $\mathrm{C} 1 / \mathrm{H} 1$ & $\mathrm{C} 2 / \mathrm{H} 2$ & $\mathrm{C} 3 / \mathrm{H} 3$ & $\mathrm{C} 4 / \mathrm{H} 4$ & С5/H5 \\
\hline Химический сдвиг, м. д. & $101.6 / 4.44$ & $72.9 / 3.24$ & $73.2 / 3.51$ & $76.2 / 3.74$ & $62.7 / 3.31$ и 4.04 \\
\hline Отнесение & $\mathrm{C} 1{ }^{\prime} / \mathrm{H} 1$ & $\mathrm{C} 2 \mathrm{~S} / \mathrm{H} 2 \mathrm{~S}$ & $\mathrm{C} 3 \mathrm{~S} / \mathrm{H} 3 \mathrm{~S}$ & $\mathrm{C} 4 / \mathrm{H}^{\prime}$ & С5"/H5" \\
\hline Химический сдвиг, м. д. & $99.3 / 5.12$ & $72.4 / 4.42$ & $72.2 / 4.74$ & $74.3 / 3.92$ & $58.6 / 3.80$ и 4.39 \\
\hline
\end{tabular}

Следует отметить, что из-за перекрывания некоторых пиков анализа только химических сдвигов ${ }^{13} \mathrm{C}$ для их достоверного отнесения к конкретным атомам углерода оказалось недостаточно и часть информации была получена из спектров HSQC с DEPT редактированием (рис. 5, табл. 3).

\section{Заключение}

Впервые предложено осуществлять в среде 1,4-диоксана сульфатирование ксилана сульфаминовой кислотой в присутствии мочевины. Установлено, что наиболее высокое содержание серы в полученных сульфатах ксилана (16,8-17,5 \% масс.) достигается при температуре 90 $100{ }^{\circ} \mathrm{C}$ и продолжительности сульфатирования 4-5 ч. Методом ЯМР-спектроскопии показано, что в процессе сульфатирования происходит частичное замещение гидроксильных групп при $\mathrm{C} 2$ и $\mathrm{C} 3$ углеродных атомах $\beta$-D-ксилопиранозных звеньев ксилана. По сравнению с сульфатированием ксилана в среде пиридина и ДМФА 1,4-диоксан не образует производных с продуктом сульфатирования, что повышает чистоту получаемых сульфатов ксилана.

\section{Благодарности / Acknowledgments}

Работа выполнена в рамках государственного задания Института химии и химической технологии СО РАН (проект 0287-2021-0017) с использованием оборудования Красноярского регионального центра коллективного пользования ФИЦ КНЦ СО РАН.

This work was conducted within the framework of the budget project 0287-2021-0017 for Institute of Chemistry and Chemical Technology SB RAS using the equipment of Krasnoyarsk Regional Research Equipment Centre of SB RAS.

\section{Список литературы / References}

1. Ebringerová A., Hromádková Z., Heinze T. Hemicellulose. Adv. Polym. Sci. 2005. Vol. 186, P. 1-67. DOI: https://doi.org/10.1007/b136816

2. Капуцкий Ф.Н., Соловьева Л. В., Торгашов В. И., Зубец О. В., Ивашкевич О. А. Химическая модификация ксиланов для их применения в фармации. Сб. $\mathrm{cm}$. «Свиридовские чтения». Минск: БГУ, 2014. (10). С. 277-287. [Kaputskiy F.N., Solov'eva L.V., Torgashov V.I., Zubets O.V., Ivashkevich O. A. Chemical modification of xylanes for their application in pharmacy. Collection of research papers «Sviridovskie chteniya». Minsk: BSU, 2014. (10). P. 277-287. (in Russ.)] 
3. Naidu D. S., Hlangothi S.P., John M. J. Bio-based products from xylan: A review. Carbohydr. Polym. 2018. Vol. 179, P. 28-41. DOI: https://doi.org/10.1016/j.carbpol.2017.09.064

4. Mendes F.R.S., Bastos M.S.R., Mendes L.G., Silva A.R.A., Sousa F.D., Monteiro-Moreira A.C.O., Cheng H.N., Biswas A., Moreira R.A. Preparation and evaluation of hemicellulose films and their blends. Food Hydrocoll. 2017. Vol. 70, P. 181-190. DOI: https://doi.org/10.1016/j. foodhyd.2017.03.037

5. Mestechkina N.M., Shcherbukhin V.D. Sulfated polysaccharides and their anticoagulant activity: A review. Appl. Biochem. Microbiol. 2010. Vol. 46(3), P. 267-273. DOI: https://doi.org/10.1134/ S000368381003004X

6. Anderson V.R., Perry C.M. Pentosan Polysulfate: A Review of its use in the relief of bladder pain or discomfort in interstitial cystitis. Drugs. 2006. Vol. 66, P. 821-835. DOI: https://doi. org/10.2165/00003495-200666060-00006

7. Mandal P., Pujol C. A., Damonte E. B., Ghosh T., Ray B. Xylans from scinaia hatei: structural features, sulfation and anti-HSV activity. Int. J. Biol. Macromol. 2010. Vol. 46(2), P. 173-178. DOI: https://doi.org/10.1016/j.ijbiomac.2009.12.003

8. Ragab T. I.M., AmerH., Mossa A. T., Emam M., Hasaballah A. A., Helmy W. A. Anticoagulation, fibrinolytic and the cytotoxic activities of sulfated hemicellulose extracted from rice straw and husk. Biocatal. Agric. Biotechnol. 2018. Vol. 15. P. 86-91. DOI: https://doi.org/10.1016/j.bcab.2018.05.010

9. Sun J.X., Sun X.F., Sun R.C., Su Y.Q. Fractional extraction and structural characterization of sugarcane bagasse hemicelluloses. Carbohydr. Polym. 2004. Vol. 56(2), P. 195-204. DOI: https://doi. org/10.1016/j.carbpol.2004.02.002

10. Patent 9120877 US. Stajic V., Cheetham N., Bell A. Sulfated polysaccharide compound and the preparation and the use thereof. Publ. Date 01.09.2015.

11. Daus S., Petzold-Welcke K., Kotteritzsch M., Baumgaertel A., Schubert U.S., Heinze T. Homogeneous sulfation of xylan from different sources. Macromol. Mater. Eng. 2011. Vol. 296(6), P. 551-561. DOI: https://doi.org/10.1002/mame.201000390

12. Yamagaki T., Tsuji Y., Maeda M., Nakanishi H. NMR spectroscopic analysis of sulfated B-1,3-xylan and sulfation stereochemistry. Biosci. Biotechnol. Biochem. 1997. Vol. 61(8), P. 1281-1285. DOI: https://doi.org/10.1271/bbb.61.1281

13. Gabriel L., Günther W., Pielenz F., Heinze T. Determination of the binding situation of pyridine in xylan sulfates by means of detailed NMR studies. Macromol. Chem. Phys. 2020. Vol. 221(1), P. 1900327. DOI: https://doi.org/10.1002/macp.201900327

14. Pfeifer A., Heinze T. Synthesis of pyridine-free xylan sulfates. Carbohydr. Polym. 2019. Vol. 206. P. 65-69. DOI: https://doi.org/10.1016/j.carbpol.2018.10.119

15. Levdansky V.A., Kondrasenko A.A., Levdansky A. V., Kuznetsov B. N. Sulfation of xylan with sulfamic acid in N, N-dimethylformamide. Russ. J. Bioorg. Chem. 2019. Vol. 45(7), P. 882-887. DOI: https://doi.org/10.1134/S1068162019070057

16. Vasilyeva N. Yu., Levdansky A.V., Kuznetsov B.N., Skvortsova G.P., Kazachenko A. S., Djakovitch L., Pinel C. Sulfation of arabinogalactan by sulfamic acid in dioxane. Russ. J. Bioorg. Chem. 2015. Vol. 41(7), P. 725-731. DOI: https://doi.org/10.1134/S1068162015070158

17. Chen Y., Sun X., Shan J., Tang C., Hu R., Shen T., Qia H., Li M., Zhuang W., Zhu C., Ying H. Flow synthesis, characterization, anticoagulant activity of xylan sulfate from sugarcane 
bagasse. Int. J. Biol. Macromol. 2020. Vol. 155, P. 1460-1467. DOI: https://doi.org/10.1016/j. ijbiomac.2019.11.124

18. Базарнова Н.Г., Карпова Е.В., Катраков И.Б., Маркин В.И., Микушина И.В., Ольхов Ю.А., Худенко С.В. Методы исследования древесины и ее производных. Барнаул: Изд-во Алт. гос. ун-та, 2002. 160 с. [Bazarnova N. G., Karpova E.V, Katrakov I.B, Markin V.I., Mikushina I. V., Ol'khov Yu.A, Khudenko S. V. Methods for the study of wood and its derivatives. Barnaul: Publishing House of Alt. state. Univ, 2002. 160 p. (in Russ.)].

19. Ruiz-Matute A.I., Hernández-Hernández O., Rodríguez-Sánchez S., Sanz M.L., MartínezCastro I. Derivatization of carbohydrates for GC and GC-MS analyses. J. Chromatogr. B. 2011. Vol. 879(17-18), P. 1226-1240. DOI: https://doi.org/10.1016/j.jchromb.2010.11.013

20. Bhagia S., Pu Y., Evans B. R., Davison B.H., Ragauskas A. J. Hemicellulose characterization of deuterated switchgrass. Bioresour. Technol. 2018. V. 269. P. 567-570. DOI: https://doi.org/10.1016/j. biortech.2018.08.034

21. Kačuráková M., Wellner N., Ebringerová A., Hromádková Z., Wilson R., Belton P. Characterisation of xylan-type polysaccharides and associated cell wall components by FT-IR and FT-Raman spectroscopies. Food Hydrocoll. 1999. Vol. 13(1), P. 35-41. DOI: https://doi.org/10.1016/ S0268-005X(98)00067-8 